\title{
Economic Optimization of a Hybrid Solar-Wind Power Plant in Chile
}

\author{
José O. Maldifassi ${ }^{1}$, Julián Lizama M. ${ }^{1}$ and Ignacio Mongillo M. ${ }^{2}$ \\ ${ }^{1}$ School of Engineering and Science \\ Universidad Adolfo Ibáñez \\ Avda. Padre Hurtado 750, Viña del Mar, Chile \\ Phone: 56-32-250 3753 ; e-mail: jose.maldifassi@uai.cl; julimux@ gmail.com \\ ${ }^{2}$ Servicios Logísticos; Arauco S.A. \\ El Golf 150, piso 13. Las Condes \\ Santiago, Chile \\ Phone: 56-2-2461 7200 ; e-mail: ignaciomongillo@gmail.com
}

\begin{abstract}
This study analyzes the optimal configuration of a hybrid solar-wind power plant in terms of levelized electricity generating costs for a period of 20 years. In spite that the site for the plant has one of the most intense solar radiation levels in the world, the final result is that only wind generators should be used to provide electricity to the nearby Chuquicamata mining complex in northern Chile.
\end{abstract}

Key words: hybrid, solar, wind, costs, Chile

\section{Introduction}

Codelco-Chile is the company that produces the largest amount of copper worldwide. Of the most important mining countries Chile has the second highest electricity tariff only after Congo, with $12.1 \mathrm{US} \phi / \mathrm{KWh}^{1}$. Of Codelco's production costs $13.7 \%$ are electricity expenses and its reduction is an important operational goal. These high operational costs due to high electricity tariffs could help justifying in economic terms the construction of a power plant based on renewable energies, particularly in the northern part of Chile where solar radiation is one of the most intense worldwide, and where the proximity to the sea provides abundant winds. For this purpose Coldelco is considering the construction of a hybrid solarwind power plant located in an available site, close to the Chuquicamata mining complex. A hybrid power plant was considered because of the complementarity (Luna-Rubio et al. 2011) of maximum solar radiation at midday and strongest winds at sunrise and sunset in the area.

The available site for the project has an approximate area of $28.4\left[\mathrm{Km}^{2}\right]$, is located close to the city of Calama at an altitude of 2490 [m], and it has desert-like characteristics. Close to the site there are four power substations adequate for conveniently connecting the power lines of the proposed generating plant to the grid.

\footnotetext{
${ }^{1}$ As of June 2013
}

In the past years the Cuquicamata mining complex has had an average power demand of 245 [MW], with $80 \%$ of the time exhibiting demands in the 220 [MW] -270 [MW] range. This power demand is expected to grow at an average rate of $3 \%$ to $4 \%$ per year. Currently this electricity is supplied by the Northern Interconnected System (Sistema Interconectado del Norte Grande SING), with prices that varies along the day, with a maxima at midday and a minima at midnight.

Figure 1 exhibits de average demand along the day and the average electric power supplied by the SING for the years from 2008 to 2012 .

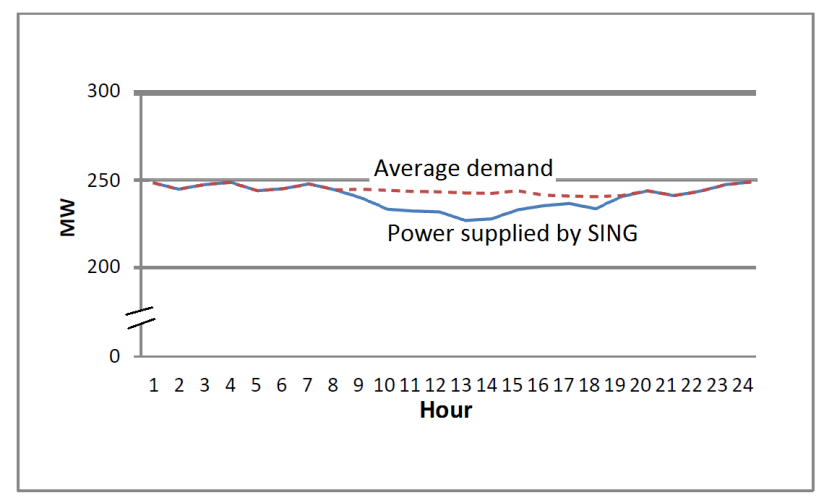

Figure 1. Demand of the Chuquicamata mining complex

As can be seen in Figure 1, at midday there is a power deficit, currently covered by a self-generation gas power plant that supplies part of the electricity demanded at a lower cost than the peak price charged by contracted suppliers. According to Alonso (2012) for Codelco as a whole, the average price of electricity for the year 2011 was $12.5 \mathrm{US} \notin / \mathrm{KWh}$, much higher than other copper producing Latin American countries and above the world average, resulting in higher costs and lower margins.

According to Chilean legislation, because of its large power demand, Codelco has to purchase electricity by contracting directly with generating companies, contracts 
that are not disclosed to the public. Therefore it is not possible to know exactly the prices charged by these suppliers.

In the Chilean electricity market generating companies have to report to the National Energy Commission (CNE) the prices charged to large contracted consumers ${ }^{2}$, these include the cost of energy and of power. The prices reported are averaged and the Average Market Price (PMM) is used to calculate the electricity price for specific grid "knots" 3 . Therefore the PMM is a good approximation to the prices charged by generating companies to large consumers.

On average, between the years 2009 and 2013, the PMM was $25.42 \%$ higher than marginal energy generating costs. For this study it has been assumed that the cost of electricity for Codelco-Chuquicamata per Kwh is going to be $30 \%$ higher than the marginal cost of energy in the Crucero knot of the SING, the closest one to the mine. Using data provided by the Operations Center of the SING (CDEC-SING), the projected marginal cost of energy for the Crucero knot for the next 15 years is shown in Figure 2 .

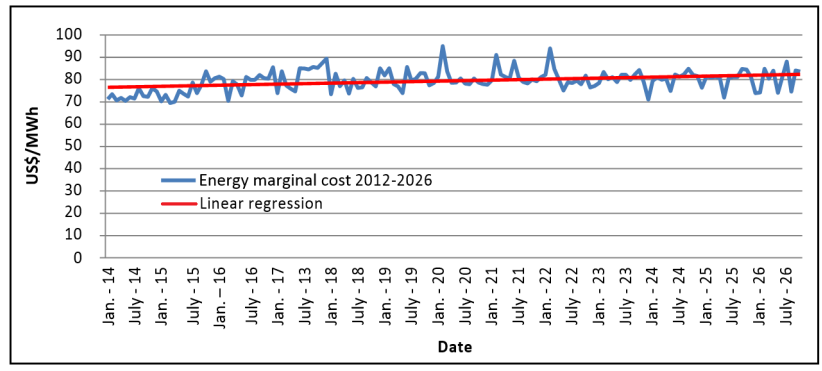

Figure 2 Expected Marginal Energy Prices 2014-16

The expected price increases for the next 15 years means that operations costs for Codelco will rise accordingly, therefore its margin will be less along time, reducing profits. This scenario looks highly inconvenient, therefore alternatives for reducing electricity costs have been studied, among which the hybrid plant analysed her is one of them.

\section{Objectives}

The objectives of this study were to appraise the capability of the available site to provide solar and wind energy for electricity generation during peak hours, and to assess the economic feasibility of such a power generating plant. For this purpose an analysis of the solar radiation levels and wind velocities was performed based on available data published by the Chilean Ministry of Energy. Based on solar PV panel costs and wind generators costs published by the Chile Energy Scenarios 2030 Working Group (2013), a linear programing (LP) optimization model was developed considering the area available on the site, the solar radiation levels, predominant winds' speed, electricity prices, and the electricity demand of the mining plant close by. Using this LP model it was

\footnotetext{
2 "Free clients" is the term used in the Chilean regulations.

${ }^{3}$ A "knot" is a highly important grid substation in the electric system, where several power lines converge.
}

analysed the number of PV solar panels and the number of wind turbines that would minimize the levelized cost of electricity for the Chuquicamata complex. With this information the NPV of the resulting power plant was calculated to assess the economic feasibility of the project.

\section{Methodology}

The main objective of the optimization model is the minimization of the overall electricity costs for the next 20 years, considering the power provided by the hybrid plant and its specific levelized costs, and the power purchased from power companies at hourly market prices.

The solar irradiance in the northern part of Chile is one of the highest in the world. For the present study solar data was obtained from the SolarGIS Database v1.8 (SOLARGIS 2013), and from the Explorador Solar data base of the Chilean Ministry of Energy (2013). This data is collected by the Geophysical Department of Universidad de Chile for the said Ministry. In the site, for a typical meteorological year (TMY) the maximum monthly average solar irradiance is $9.23\left[\mathrm{KWh} / \mathrm{m}^{2} /\right.$ day $]$ with a minimum monthly average of $4.9\left[\mathrm{KWh} / \mathrm{m}^{2} /\right.$ day]. This solar irradiance is one of the most intense in the world due to the latitude, extremely low humidity and the high altitude of the place. Figure 3 shows solar irradiance values for a TMY on the available site according to SolarGIS.

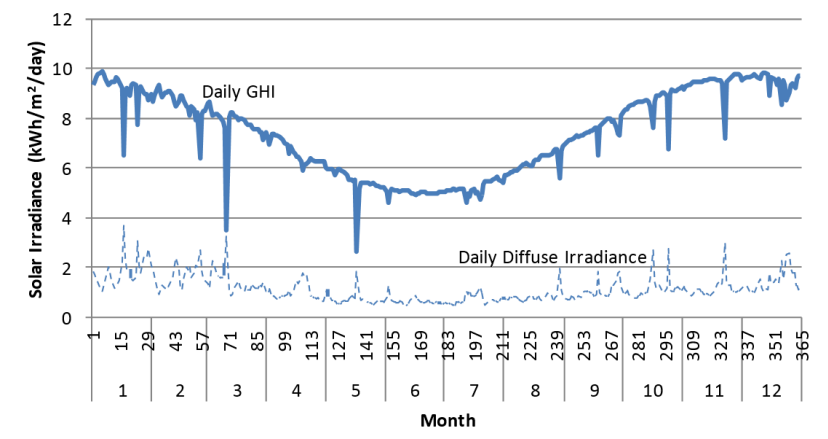

Figure 3. Solar Irradiance for a TMY on the site

For a 9-year collection period, the Explorador Solar data base provides average irradiance values every 30 minutes that were used for the optimization model.

After analysing available photovoltaic equipment ready for purchase from international suppliers, it was decided to consider the installation of 2 [MW] PV modules complete with their respective power adapters. The design of the solar module was performed by means of the PVsyst software, resulting in 437 panels connected in parallel with 15 of these arrangements connected in series; each 2 [MW] PV module utilizes four inverters and occupies $12,700\left[\mathrm{~m}^{2}\right]$, providing approximately 400 [MWh/month]. In the available site 2,000 of these 2 [MW] solar modules can be installed. For the overall cost of the solar modules, the cost figure of 2.11 [Million US\$/MW] proposed by the Chile Energy Scenarios 2030 working group was used.

In terms of costs, according to Goodrich, James and Woodhouse (2012) the cost structure of utility solar power plants can be apportioned as shown in Table 1, from where, using the 2.11 [Million US\$/MW] figure 
mentioned above, the itemized costs used in this study are as shown in the third column of Table 1 .

\begin{tabular}{|l|l|r|}
\hline Solar modules & $51 \%$ & US\$ Million 2.15 \\
\hline Inverters & $8 \%$ & 0.337 \\
\hline Installation materials & $10 \%$ & 0.422 \\
\hline Electrical labour & $9 \%$ & 0.38 \\
\hline Hardware labour & $2 \%$ & 0.085 \\
\hline Site preparation & $3 \%$ & 0.127 \\
\hline Installation & $2 \%$ & 0.085 \\
\hline Transport & $7 \%$ & 0.295 \\
\hline Owner's costs & $8 \%$ & 0.338 \\
\hline & Total & US\$ 4.22 Million \\
\hline
\end{tabular}

Table 1. Cost structure for each $2 \mathrm{MW}$ installed solar module

Wind data was obtained from the Explorador de Energía Eólica data base of the Chilean Ministry of Energy (2013) generated using the WRF 3.2 software of the National Center for Atmospheric Research of the United States. As well, primary data was collected in the year 2010 close to the site by means of a tower with sensors. Figure 4 shows the average wind velocity at 45 and at 75 meters along the year.

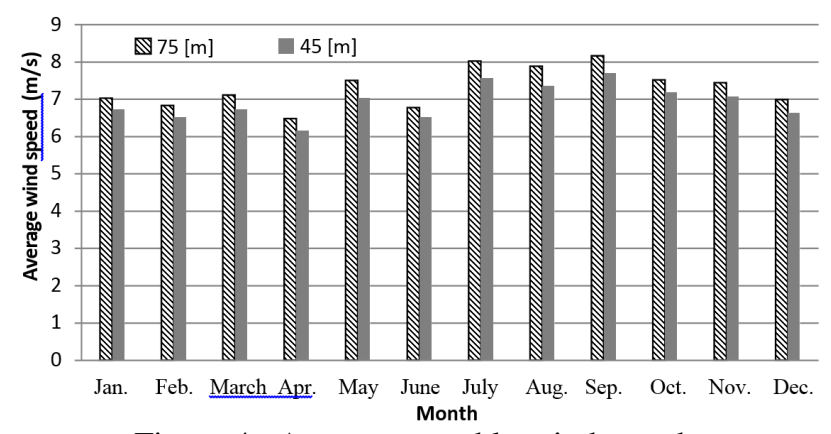

Figure 4. Average monthly wind speeds

The daily average wind velocity profile for $45[\mathrm{~m}]$ and 75 [m] is shown in Figure 5.

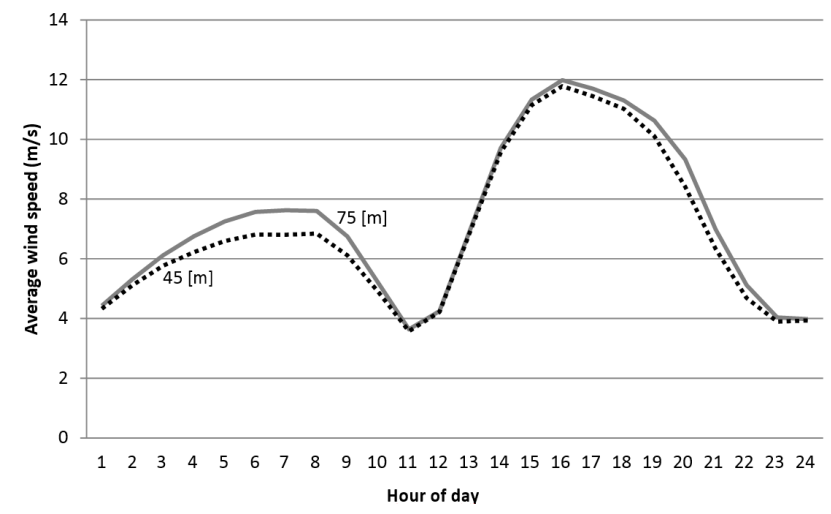

Figure 5. Average daily wind velocity at different altitudes

The early morning peak is for a NE wind, whereas the afternoon peak occurs for a SW wind. On average, a maximum speed of $7.4[\mathrm{~m} / \mathrm{sec}]$ happens at an altitude of $90[\mathrm{~m}]$.

In the case of wind, the Windographer software was used for selecting the wind turbines; the maximum availability factor for the prevailing wind was adopted as the selection criteria. A commercially available wind generator was chosen with the following characteristics: 1.8 [MW], 80 [m] hub height, and $100[\mathrm{~m}]$ rotor diameter. Each one of these units can provide approximately 500 [MWh/month]. For these units the cost figure adopted was 1.85 [Million US\$/MW] installed, as proposed by the Chile Energy Scenarios 2030 working group. Considering standard relative distances between each wind turbine, the site can accommodate a maximum of 114 wind turbines.

The detailed cost structure of wind power plants can be subdivided as shown in Table 2 according to Tegen et al. (2013), with the itemized costs for the 1.8 [MW] generators used in this study included in the third column.

\begin{tabular}{|l|c|c|}
\hline Rotor & $15 \%$ & US\$ Million 0.5 \\
\hline $\begin{array}{l}\text { Drive train and } \\
\text { generator }\end{array}$ & $37 \%$ & 1.232 \\
\hline Tower & $16 \%$ & 0.533 \\
\hline Foundations & $4 \%$ & 0.133 \\
\hline Roads and civil work & $3 \%$ & 0.10 \\
\hline Electrical interface & $8 \%$ & 0.266 \\
\hline $\begin{array}{l}\text { Turbine } \\
\text { transportation }\end{array}$ & $3 \%$ & 0.10 \\
\hline $\begin{array}{l}\text { Assembly and } \\
\text { installation }\end{array}$ & $3 \%$ & 0.10 \\
\hline Contingency & $6 \%$ & 0.20 \\
\hline Other & $6 \%$ & 0.20 \\
\hline & Total & US\$ 3.33 Million \\
\hline
\end{tabular}

Table 2. Cost structure for each 1.8 [MW] wind turbine

For the LP model there is need to know the cost of producing one unit of energy for each source. In this study the levelized cost of energy was used according to equation 1 (Darling et al. 2011).

$\mathrm{LCOE}=\frac{\sum_{\mathrm{t}=1}^{\mathrm{n}} \frac{I_{t}+M_{t}-B C_{t} * E_{t}-A_{t} * E_{t} * 0.8}{(1+\mathrm{r})^{\mathrm{t}}}-\frac{V S}{(1+\mathrm{r})^{\mathrm{t}}}}{\sum_{\mathrm{t}=1}^{\mathrm{n}} \frac{E_{t}}{(1+\mathrm{r})^{\mathrm{t}}}}$

Where:

LCOE Levelized Cost of Energy [US\$/MWh]

$\mathrm{I}_{\mathrm{t}}$ Investment year $\mathrm{t}$ [US\$]

$\mathrm{M}_{\mathrm{t}}$ Maintenance year $\mathrm{t}$ [US\$]

$\mathrm{E}_{\mathrm{t}}$ Energy produced year $\mathrm{t}$ [MWh]

$r$ Discount rate

VS Salvage value [US\$]

$\mathrm{BC}_{\mathrm{t}} \mathrm{CO}_{2}$ emissions allowance price [US\$/MWh]

$\mathrm{A}_{\mathrm{t}}$ Price of Renewable Energy Attribute ${ }^{4}$ [US\$/MWh]

The parameters used to calculate the LCOE for the 2 [MW] PV panels and the 1.8 [MW] wind turbines are

\footnotetext{
${ }^{4}$ According to Chilean regulations, electricity generating companies must meet yearly renewable energy targets. The attribute of being renewable for energy generated by a solar or wind power company can be sold to another company to be considered as generated by the buyer of the said attribute, this transaction having a market price in [US\$/MWh]. Only up to $80 \%$ of the generated renewable energy can be sold as a renewable energy attribute.
} 
listed in Table 3, together with the LCOE for each energy source.

\begin{tabular}{|l|c|c|}
\hline $\begin{array}{l}\text { Source and } \\
\text { Power }\end{array}$ & Solar 2 [MW] & Wind 1.8 [MW] \\
\hline Investment $\mathrm{I}_{0}$ & $\begin{array}{c}4.22[\mathrm{Million} \\
\mathrm{US} \$]\end{array}$ & $\begin{array}{c}3.33 \text { [Million } \\
\text { US\$] }\end{array}$ \\
\hline $\begin{array}{l}\text { Operations \& } \\
\text { Maintenance }\end{array}$ & \multicolumn{2}{|c|}{$2 \%$ of $\mathrm{I}_{0}$ yearly } \\
\hline Discount rate $\mathrm{r}$ & \multicolumn{2}{|c|}{$10 \%$} \\
\hline Salvage value & $20 \%$ of $\mathrm{I}_{0}$ & $10.3 \%$ of $\mathrm{I}_{0}$ \\
\hline $\begin{array}{l}\mathrm{CO}_{2} \text { emissions } \\
\text { allowance price }\end{array}$ & \multicolumn{2}{|c|}{$5[\mathrm{US} \$ \mathrm{MWh}]$} \\
\hline $\begin{array}{l}\text { Price of } \\
\text { Renewable } \\
\text { Energy Attribute }\end{array}$ & \multicolumn{2}{|c|}{$13[\mathrm{US} \$ / \mathrm{MWh}]$} \\
\hline $\begin{array}{l}\text { Plant availability } \\
\text { factor }\end{array}$ & $27.6 \%$ & $37.6 \%$ \\
\hline $\begin{array}{l}\text { Annual energy } \\
\text { generation }\end{array}$ & $4,690[\mathrm{MWh}]$ & $5,750[\mathrm{MWh}]$ \\
\hline Power line losses & \multicolumn{2}{|c|}{$3 \%$} \\
\hline $\begin{array}{l}\text { Annual power } \\
\text { degradation }\end{array}$ & $0.7 \%[1 / \mathrm{yr}]$ & $0[1 / \mathrm{yr}]$ \\
\hline \multicolumn{1}{|c|}{ LCOE } & $112[\mathrm{US} \$ / \mathrm{MWh}]$ & $63[\mathrm{US} \$ / \mathrm{MWh]}$ \\
\hline
\end{tabular}

Table 3. Parameters and calculated LCOE for each energy source.

Sensitivity analysis shows that for both energy sources the most important parameters that affect the LCOE are the plant availability factor and the cost of installed equipment. As can be seen in Table 3, these two parameters are the ones that differentiate the most between the solar modules and the wind turbines, clearly explaining the significant difference of their respective LCOEs.

Taking into consideration the hourly prices of electricity purchased from the SING, the LCOE for each energy source as calculated in Table 3 and the expected electricity demand of the Chuquicamata mining complex, the optimization LP model minimizes the cost of buying electricity for Codelco. Its formulation is as follows:

\section{Decision variables:}

$\mathrm{X}$ Number of $2[\mathrm{MW}]$ solar modules

$\mathrm{Y}$ Number of $1.8[\mathrm{MW}]$ wind turbines

\section{Parameters:}

$n$ Number of days to include in the assessment (7,300 days for a 20-year horizon)

$m$ Hour of day $(1-24)$

MX Maximum number of solar modules $(2,000)$

MY Maximum number of wind turbines (114)

$\mathrm{LCOE}_{\mathrm{S}}$ Levelized cost of solar energy [US\$/KWh]

$\mathrm{LCOE}_{\mathrm{E}}$ Levelized cost of wind energy [US $\$ / \mathrm{KWh}$ ]

CRij Price of energy for hour i in day j purchased from the SING [US\$/KWh]

ESij Energy produced by each solar module at hour i in day $\mathrm{j}$ [KWh], hour by hour daily average for each month EEij Energy produced by each wind turbine at hour i in day j [KWh], hour by hour daily average for each month
CEij Energy consumption of the mine at hour $\mathrm{i}$ in day $\mathrm{j}$ [KWh]

Equations:

$\mathrm{ESTij}=\mathrm{ESij} * \mathrm{Y} \quad[\mathrm{KWh}]$

Energy produced by the solar modules at hour $\mathrm{i}$ in day $\mathrm{j}$

$\mathrm{EETij}=\mathrm{EEij} * \mathrm{X} \quad[\mathrm{KWh}]$

Energy produced by the wind turbines at hour $\mathrm{i}$ in day $\mathrm{j}$

ERij $=$ CEij $-($ EETij + ESTij $) \quad[$ KWh $]$

Energy purchased from the SING at hour $i$ in day $j$

CTij $=$ ESTij $^{*} \mathrm{LCOE}_{\mathrm{S}}+\mathrm{EETij}^{*} \mathrm{LCOE}_{\mathrm{E}}+\mathrm{ERij}^{*} \mathrm{CRij}$

Cost of energy at hour $\mathrm{i}$ in day $\mathrm{j}$ [US\$]

\section{Objective function:}

$$
\text { Min. } C T=\sum_{j=1}^{7,300} \sum_{i=1}^{24} C T i j
$$

CT Total cost of energy for the 20 year period [US\$]

\section{Restrictions:}

$$
\begin{aligned}
& \mathrm{X} \leq \mathrm{MX} \\
& \mathrm{Y} \leq \mathrm{MY} \\
& \mathrm{X} \in \mathbf{N}_{0} \\
& \mathrm{Y} \in \mathbf{N}_{0}
\end{aligned}
$$

Using this LP model four scenarios were analyzed: a) prices increasing historically along time (probability $0.65^{5}$ ); b) $10 \%$ increase of fuel prices (probability 0.1 ); c) $20 \%$ increase in demand (probability 0.15); d) demand and fuel prices increasing simultaneously (probability 0.10). The model was written using the Large Scale Solver for Microsoft Excel.

\section{Results and conclusions}

As was mentioned, the overall objective for the hybrid power station was the minimization of the electricity costs for the Chuquicamanta mining complex. For the first three scenarios mentioned, for an estimated joint probability of 0.9 , the optimal solution is the installation of the 114 wind turbines that the site can accommodate and no solar modules, totalling 205 [MW], whereas in the fourth scenario, where fuel prices and demand increase simultaneously, besides the 114 wind turbines, 92 solar modules should be added, totalling 389 [MW], this scenario having only an estimated 0.1 probability of occurrence.

Sensitivity analysis was done in terms of the LCOE for each source and for each scenario. In the first of these, solar modules appear in the solution only if the LCOE for this energy source decreases from 112 to 83 [US\$/MWh], that is, after a $26 \%$ reduction. On the other hand, the LCOE for wind turbines would have to rise from 63 to 86 [US\$/MWh], a $36.5 \%$ increase, for wind to cease being a convenient solution for the hybrid plant. A whole set of combinations are obtained using different values of LCOE

\footnotetext{
${ }^{5}$ These probabilities were provided by an engineer of the
} consulting firm Hatch, Santiago office, Chile. 
for each source within these extreme figures; only if simultaneously the LCOE for wind increases above 86 [US\$/MWh] and the LCOE for solar increases above 84 [US $\$ / \mathrm{MWh}$ ] the result of the model indicates that the plant should not be built ${ }^{6}$. As capital costs for these two energy sources have been decreasing along time (Escobar 2012; Lantz, Hand and Wiser 2012), it is very unlikely that the hybrid plant should not be built because of high generating costs of the renewable sources.

After the optimization results were obtained, an economic assessment in terms of NPV for the 114 wind turbines was carried out, considering the parameters listed in Table 3. In this case income was considered as the net savings obtained with the electricity supplied by the wind power plant. Now, to the overall costs of the project, there is need to add the cost of installing the 220 [KV] power lines to the nearest substation, that were estimated at US $\$ 4.3$ million. It was assumed that the project would be built by an independent organization that would need to pay a $20 \%$ tax rate.

The monetary flows of the project and their NPV were calculated using Microsoft Excel and the sensitivity analysis of the four scenarios by means of the software Cristal Ball of Oracle.

For an initial investment of US\$ 384 million, the overall results of the assessment indicate that with $95 \%$ of certainty the NPV of the project would vary between US\$ 50 million and US\$ 115.4 million, with a payback time between 15.7 and 9.3 years, these figures demonstrating that this project is highly convenient.

Taking into consideration the extremely high solar irradiance in the area, if for practical reasons 30 [MW] of solar generation are forced into the assessment, the NPV of the project decreases on average by US\$ 18.5 million, further corroborating the results of the LP optimization model.

\section{References}

"Escenarios Energéticos Chile 2030: Visiones y temas clave para la matriz eléctrica". Santiago, Chile (2013). Report prepared by the working group and available in the webpage

http://escenariosenergeticos.cl/wp-

content/uploads/Escenarios_Energeticos_2013.pdf

(accessed July 15, 2013)

Luna-Rubio, Ricardo; Trejo-Perea, M. Vargas-Vázquez, D. Ríos-Moreno, G.J. "Optimal sizing of renewable hybrids energy systems: A review of methodologies", Solar Energy Volume 86, Issue 4, April 2012, Pages 1077-1088.

Darling, Seth B.; Fengqi You, Thomas Veselka and Alfonso Velosa. "Assumptions and the levelized cost of energy for photovoltaics”. Energy Environ. Sci., 2011,4, 3133-3139.

\footnotetext{
${ }^{6}$ Similar sensitivity analysis were done for the other three scenarios. For further results please contact the authors.
}

Escobar, José Ignacio, Executive Vice President of ACERA, Asociación Chilena de Energías Renovables. "Las ERNC y su potencial contribución en generación". Santiago, Chile, 2012. Available in the webpage http://www.amchamchile.cl/sites/default/files/Jos\%C3\%A 9\%20Ignacio\%20Escobar.\%20ACERA.pdf (accessed August 25, 2013)

Lantz, Eric; Maureen Hand and Ryan Wiser. "The Past and Future Cost of Wind Energy: Preprint". Presented at the 2012 World Renewable Energy Forum Denver, Colorado May 13-17, 2012.

SOLARGIS, 2013. Web page http://solargis.info/imaps/\#tl=GeoModel:dni_yr_avg\&l=0 \&loc=-23.241346,-68.90625\&c=14.264383,-69.785156 (accessed July 29, 2013)

Explorador Solar data base of the Chilean Ministry of Energy, 2013. Web page http://walker.dgf.uchile.cl/Explorador/Solar2/ (accessed July 25, 2013)

Explorador Eólico data base of the Chilean Ministry of Energy, 2013. Web page http://walker.dgf.uchile.cl/Explorador/Eolico2/ (accessed August 12, 2013)

Goodrich, Alan; Ted James and Michael Woodhouse. "Residential, Commercial, and Utility-Scale Photovoltaic (PV) System Prices in the United States: Current Drivers and Cost-Reduction Opportunities". National Renewable Energy Laboratory, U.S. Department of Energy. February 2012.

Tegen, S.; M. Hand, B. Maples, E. Lantz P. Schwabe, and A. Smith. "2011 Cost of Wind Energy Review". National Renewable Energy Laboratory, U.S. Department of Energy, March 2013. 